\title{
RESEARCH
}

Open Access

\section{Restoration of regulatory B cell deficiency following alemtuzumab therapy in patients with relapsing multiple sclerosis}

Yeseul Kim ${ }^{1,3}$, Gayoung Kim, Hyun-June Shin ${ }^{2}$, Jae-Won Hyun², Su-Hyun Kim², Eunjig Lee ${ }^{3}$ and Ho Jin Kim ${ }^{1,2^{*}}$ (D)

\begin{abstract}
Background: Regulatory B cells (Bregs), which protect from autoimmunity, are deficient in multiple sclerosis (MS). Novel regulatory B cell subsets $\mathrm{CD} 19^{+} \mathrm{CD} 24^{\mathrm{hi}} \mathrm{CD} 38^{\text {hi }}$ cells and CD19+PD-L1 $1^{\text {hi }}$ cells, with disparate regulatory mechanisms have been defined. Alemtuzumab provides a long-lasting suppression of disease activity in MS. In contrast to its documented efficacy, alemtuzumab's mechanism of action is not fully understood and information about the composition of repopulating B cell pool is scarce.
\end{abstract}

Aim: To characterize repopulated B cell subsets and elucidate alemtuzumab's mechanism of action in B cell perspective.

Methods: The frequency and the absolute number of Bregs were studied in peripheral blood mononuclear cells (PBMC) of $37 \mathrm{MS}$ patients and 11 healthy controls (HC). Longitudinal analysis of the frequency and the absolute number of Bregs in PBMC of 11 MS patients was evaluated, before and at 6, 9, and 12 months post alemtuzumab.

Results: We found deficiency of $\mathrm{CD} 19^{+} \mathrm{CD} 24^{\text {hi }} \mathrm{CD} 38^{\text {hi }}$ cells during relapse compared to remission and $\mathrm{HC}$ (relapse vs remission: $p=0.0006$, relapse vs HC: $p=0.0004)$. CD19+PD-L $1^{\text {hi }}$ cells were deficient during relapse than remission and HC (relapse vs remission: $p=0.0113$, relapse vs HC: $p=0.0007$ ). Following alemtuzumab, the distribution of $\mathrm{B}$ cells shifts towards naïve phenotype and Breg deficiency is restored. The frequency of $C D 19^{+} C D 24^{\text {hi }} C D 38^{\text {hi }}$ cells was significantly increased at $6 \mathrm{M}$ and $9 \mathrm{M}$ compared to $0 \mathrm{M}(6 \mathrm{M}$ vs $0 \mathrm{M}: p=0.0004,9 \mathrm{M}$ vs $0 \mathrm{M}: p=0.0079$ ). At $9 \mathrm{M}$, the frequency of $\mathrm{CD} 19^{+} \mathrm{CD} 24^{\text {hi }} \mathrm{CD} 38^{\text {hi }}$ cells started to decrease and by $12 \mathrm{M}$ the frequency was reduced compared to $6 \mathrm{M}$, although it was significantly higher than baseline level (12 M vs $0 \mathrm{M}: p=0.0257)$. The absolute number was significantly increased at $6 \mathrm{M}$ and $9 \mathrm{M}$ post-alemtuzumab ( $6 \mathrm{M}$ vs $0 \mathrm{M}: p=0.0063,9 \mathrm{M}$ vs $0 \mathrm{M}: p=0.02$ ). The frequency of CD19+PD-L1 ${ }^{\text {hi }}$ cells significantly increased until $12 \mathrm{M} \mathrm{(6} \mathrm{M} \mathrm{vs} 0 \mathrm{M}: p=0.0004,12 \mathrm{M}$ vs $\left.0 \mathrm{M}: p=0.0036\right)$. The frequency of $C D 19^{+} \mathrm{PD}-\mathrm{L} 1^{\text {hi }}$ cells at $12 \mathrm{M}$ was significantly higher than $9 \mathrm{M}(p=0.0311)$. We further pinpoint that $\mathrm{CD} 19^{+} \mathrm{CD} 24^{\text {hi }} \mathrm{CD} 38^{\text {hi }}$ cells were deficient at severe relapses following alemtuzumab infusion and restored during recovery.

Conclusions: Our results highlight the preferential reconstitution of Bregs as a possible mechanism of action of alemtuzumab and $\mathrm{CD} 19^{+} \mathrm{CD} 24^{\text {hi }} \mathrm{CD} 38^{\text {hi }}$ cells as a potential biomarker for disease activity.

Keywords: Multiple sclerosis, Regulatory B cells, Alemtuzumab, Relapse

\footnotetext{
* Correspondence: hojinkim@ncc.re.kr

'Division of Clinical Research, Research institute, National Cancer Center,

Goyang, Korea

${ }^{2}$ Department of Neurology, Research Institute and Hospital of National

Cancer Center, Goyang, Korea

Full list of author information is available at the end of the article
}

(c) The Author(s). 2018 Open Access This article is distributed under the terms of the Creative Commons Attribution 4.0 International License (http://creativecommons.org/licenses/by/4.0/), which permits unrestricted use, distribution, and reproduction in any medium, provided you give appropriate credit to the original author(s) and the source, provide a link to the Creative Commons license, and indicate if changes were made. The Creative Commons Public Domain Dedication waiver (http://creativecommons.org/publicdomain/zero/1.0/) applies to the data made available in this article, unless otherwise stated. 


\section{Background}

The concept that multiple sclerosis (MS) is a T-cell-mediated disease has been changed and it is now widely accepted that B cells play a part in the pathogenesis of MS. [1-3] Multiple roles of B cells have been elucidated emphasizing that $\mathrm{B}$ cells have dual contribution to autoimmunity [1, 4-6]. Hence, the concept of regulatory B cells (Breg) has emerged, proving that B cell subset distribution is far more complex than the original concept. A novel Breg subset that was originally known as immature transitional B cells $\left(\mathrm{CD} 19^{+} \mathrm{CD} 24^{\mathrm{hi}} \mathrm{CD} 38^{\mathrm{hi}}\right)$ has been described to have regulatory capacity through interleukin-10 production [7]. Another study has found B cells highly expressing programmed death ligand-1 (CD19 ${ }^{+} \mathrm{PD}-\mathrm{L} 1^{\text {hi }}$ cells) that exert regulatory function through cell-to-cell contact via interaction of $\mathrm{CD} 19^{+} \mathrm{PD}-\mathrm{L} 1^{\text {hi }}$ cells with PD- 1 on $\mathrm{T}$ cells, resulting in suppression of $\mathrm{T}$ follicular helper (Tfh) cell differentiation and expansion, which are the cell type known to be involved in the relapse of MS patients $[8,9]$.

Alemtuzumab is a highly effective treatment in relapsing MS. It provides a long-lasting suppression of disease activity by altering the proportion of lymphocyte subsets with preferential increase of regulatory T cells (Treg) [10, 11]. In contrast to alemtuzumab's documented efficacy, alemtuzumab's mechanism of action is not fully understood and information about the composition of the repopulating $\mathrm{B}$ cell pool, especially Breg, is scarce.

Here, we pinpoint deficiency of $\mathrm{CD} 19^{+} \mathrm{CD} 24^{\mathrm{hi}} \mathrm{CD} 38^{\mathrm{hi}}$ and $\mathrm{CD} 19^{+} \mathrm{PD}-\mathrm{L} 1^{\text {hi }}$ cells during relapse and subsequent expansion following alemtuzumab infusion. We also highlight the possible clinical implication of $\mathrm{CD} 19^{+} \mathrm{CD} 24^{\text {hi }} \mathrm{CD} 38^{\text {hi }}$ cells.

\section{Methods}

\section{Study population}

For cross-sectional study, $20 \mathrm{MS}$ patients during relapse (MS-relapse) and 17 MS patients in remission (MS-remission) and 11 healthy controls $(\mathrm{HC})$ were included. For longitudinal analysis, 11 patients who were treated with alemtuzumab were included. All MS patients fulfilled the 2010 McDonald's criteria [12]. Current study was approved by the Institutional Review Board, and informed consent was obtained from each subject. Demographic and clinical characteristics of participants are summarized in Table 1.

\section{Flow cytometry}

For cross-sectional study, fresh peripheral blood mononuclear cells (PBMCs) were surface stained with monoclonal antibodies against CD19-APC-cy7, CD27-FITC, CD24-BV421, CD38-BV510, and PD-L1(CD274)-PE-cy7 (BD Biosciences). For longitudinal study, frozen PBMCs, collected from 11 RRMS patients undergoing alemtuzumab at baseline and 6, 9, and 12 months, were surface stained with monoclonal antibodies as stated above.
Table 1 Demographic and clinical characteristics of MS patients in relapse and remission

\begin{tabular}{lll}
\hline Characteristic & MS relapse & MS remission \\
\hline Age (years, mean \pm SD) & $34.5 \pm 9.4$ & $36.9 \pm 5.2$ \\
Women:men $(n: n)$ & $16: 4$ & $10: 7$ \\
Onset age (years, mean \pm SD) & $30.4 \pm 22.0$ & $29.8 \pm 7.3$ \\
Disease duration (years, mean \pm SD) & $12 \pm 24.9$ & $6 \pm 5.9$ \\
EDSS (mean \pm SD) & $2.9 \pm 1.9$ & $1.8 \pm 1.9$ \\
\hline
\end{tabular}

\section{Statistical analysis}

We performed analysis of significance in Prism (GraphPad, La Jolla, USA). For cross-sectional data, one-way ANOVA analysis with Tukey's multiple comparison post hoc analysis was performed to compare the frequency of Bregs between HC, MS-relapse, and MS-remission. Unpaired $t$ test was used to compare the absolute number of Bregs between MS-relapse and MS-remission. Repeated measures ANOVA with Tukey's multiple comparison post hoc analysis was performed for longitudinal analysis. A $p$ value of $<0.05$ was considered statistically significant. All values show mean \pm SEM.

\section{Result \\ Regulatory B cells are deficient in MS patients during relapse}

In order to evaluate the relationship between the frequency of $\mathrm{CD} 19^{+} \mathrm{CD} 24^{\mathrm{hi}} \mathrm{CD} 38^{\text {hi }}$ cells and CD $19^{+} \mathrm{PD}-\mathrm{L} 1^{\text {hi }}$ cells with disease activity of MS, the frequency and the absolute number were measured in total $\mathrm{CD} 19^{+} \mathrm{B}$ cells in MS-relapse and MS-remission and HC. The frequency of both CD $19^{+}$CD $24^{\text {hi }}{ }^{2}$ 3 $38^{\text {hi }}$ cells (Fig. $1 \mathrm{a}, \mathrm{b}$ ) and CD $19^{+}$PD-L1 ${ }^{\text {hi }}$ cells (Fig. 2a, b) was significantly reduced in MS-relapse compared to MS-remission and $\mathrm{HC}$. The average frequency of Bregs in MS-remission was lower than those of $\mathrm{HC}$, but no statistical difference was observed. The absolute number of $\mathrm{CD} 19^{+} \mathrm{CD} 24^{\mathrm{hi}} \mathrm{CD} 38^{\text {hi }}$ cells was significantly reduced in MS-relapse compared to MS-remission (Fig. 1c). Although no significant difference was observed, the absolute number of $\mathrm{CD} 19^{+} \mathrm{PD}-\mathrm{L} 1^{\text {hi }}$ cells was reduced in MS-relapse compared to MS-remission (Fig. 2c).

\section{Preferential reconstitution of naïve B cells following alemtuzumab}

As expected, the frequency and absolute number of total lymphocytes was decreased at 6 months and gradually increased up to 12 months post alemtuzumab (Fig. 3a). The frequency and the absolute number of memory B cells and plasmablasts were significantly decreased compared to pre-treatment level, and naïve $B$ cells comprised the majority of repopulated $\mathrm{CD} 19^{+} \mathrm{B}$ cells (Fig. 3b). 


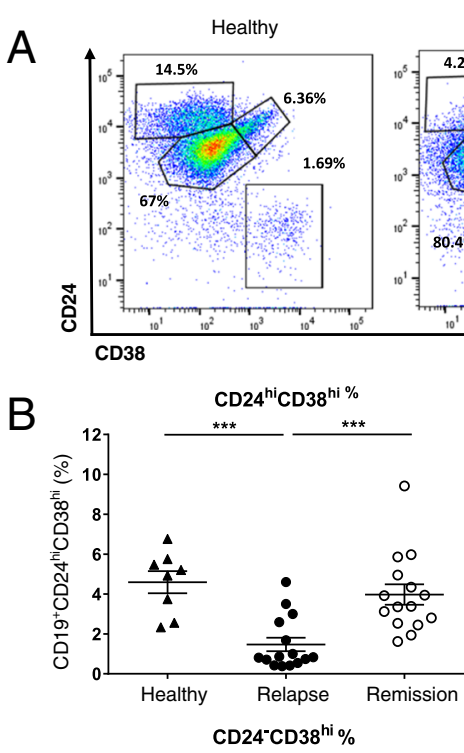

Relapse

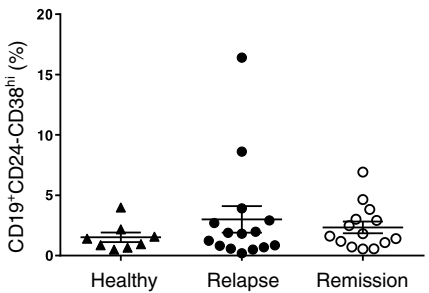

C

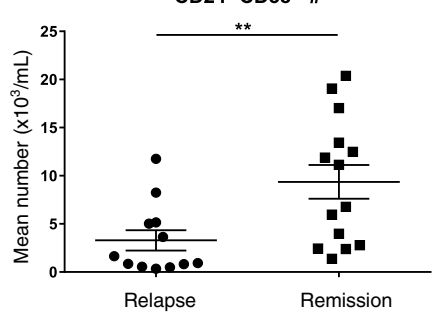

$\mathrm{CD}^{-{ }^{-}{ }^{-C D} 38^{\text {hi }}}{ }^{\text {\# }}$

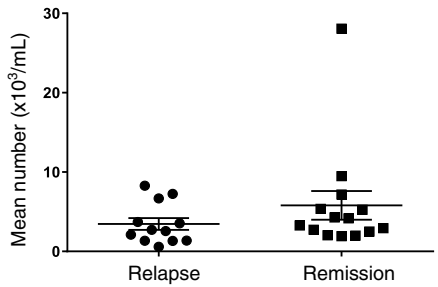

Remission

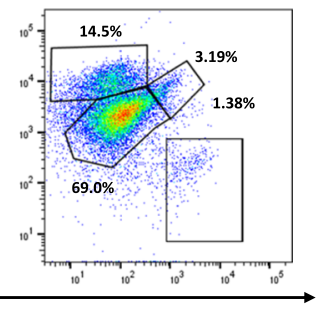

CD24 ${ }^{\text {int }} \mathrm{CD} 38^{\text {int }} \%$
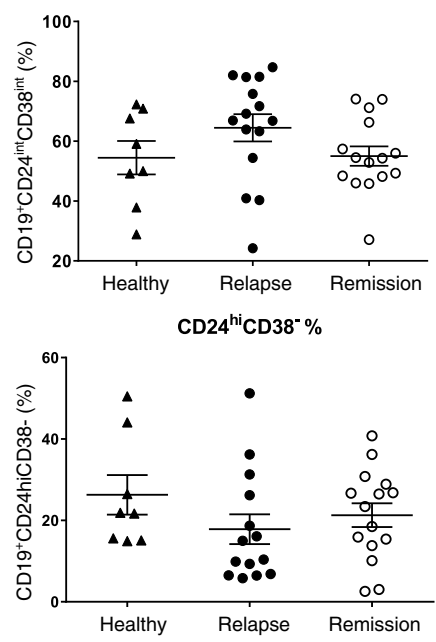

CD24 ${ }^{\text {int }}$ CD $38^{\text {int }} \#$

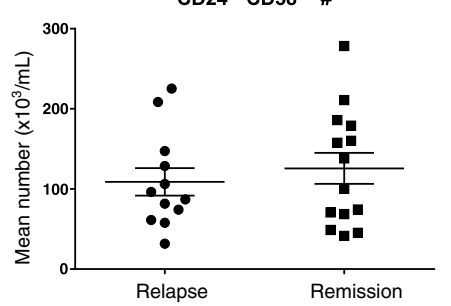

$\mathrm{CD}^{\mathrm{hi}}{ }^{\mathrm{hi}} \mathrm{CD} 38^{-} \#$

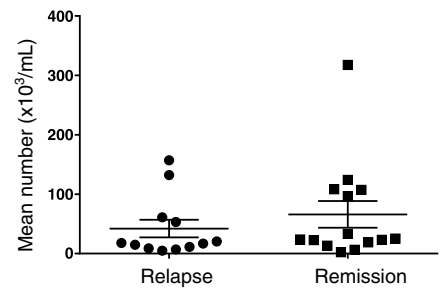

Fig. 1 MS patients show deficiency of $C D 19^{+} C D 24^{\text {hi }} C D 38^{\text {hi }}$ cells during relapse. The percentage and the absolute number of $C D 19^{+} C D 24^{\text {hi }} C D 38^{\text {hi }}$ B cells were measured in MS patients undergoing relapse $(n=15)$ and patients in remission $(n=15)$ and healthy controls $(n=8)$. PBMC was isolated from fresh peripheral blood and surface stained for flow cytometry. a Representative flow cytometry dot plot of CD24 and CD38 expression in total CD19+ B cells. b Scatter plots showing the percentage of CD19+CD24hi CD38 hi B cells in MS-relapse, MS-remission, and HC. A significant reduction in the frequency of $\mathrm{CD} 19^{+} \mathrm{CD} 24^{\text {hi }} \mathrm{CD} 38^{\text {hi }} \mathrm{B}$ cells was observed in MS-relapse compared to MS-remission and HC (relapse vs remission: $p=0.0006$, relapse vs healthy: $p=0.0004$ ). All values show mean \pm SEM. Data were analyzed by one-way analysis of variance (ANOVA) with Tukey's multiple comparison post hoc analysis. ${ }^{* * *} p<0.001$. $\mathbf{c}$ The absolute number of $C D 19^{+} C D 24^{\text {hi }} C D 38^{\text {hi }} B$ cells in MS-relapse was significantly reduced compared to MS-remission $(p=0.009)$. All values show mean \pm SEM. Data were analyzed by unpaired $t$ test. ${ }^{*} p<0.01$. Ex vivo data were collected from peripheral blood samples taken during the time course of this study 


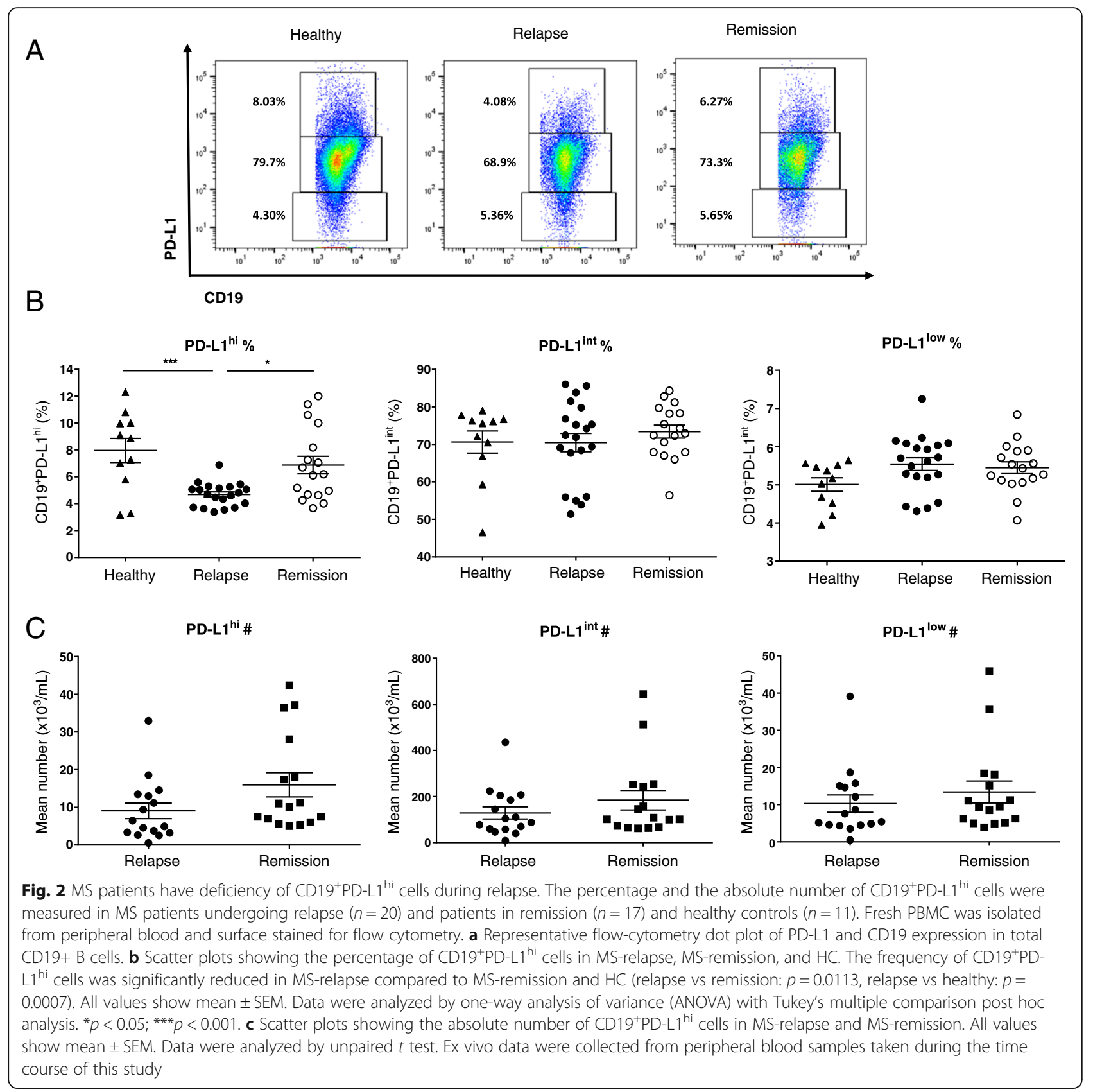

Breg deficiency in MS is restored following alemtuzumab The frequency and the absolute number of CD1 $9^{+} \mathrm{CD} 24^{\mathrm{hi}} \mathrm{CD} 38^{\text {hi }}$ cells were markedly increased at 6 and 9 months following alemtuzumab treatment compared to pre-treatment level. By the end of the cycle $(12 \mathrm{M})$, both the frequency and number were decreased, although did not reach pre-treatment level. The frequency and absolute number of $\mathrm{CD} 19{ }^{+} \mathrm{CD} 24^{\text {int }} \mathrm{CD} 38^{\text {int }}$ mature naïve $B$ cells were increased at 6 and 9 months post-alemtuzumab, and at 12 months post-alemtuzumab, the frequency of $\mathrm{CD} 19^{+} \mathrm{CD} 24^{\text {int }} \mathrm{CD} 38^{\text {int }}$ cells was lower than baseline level. A significant decrease in the frequency and absolute number of $\mathrm{CD} 19^{+} \mathrm{CD} 24^{\mathrm{hi}} \mathrm{CD} 38^{-}$ memory B cells was observed following alemtuzumab treatment (Fig. $4 \mathrm{a}-\mathrm{c}$ ).

The frequency and absolute number of CD1 $9^{+} \mathrm{PD}-\mathrm{L} 1^{\text {hi }}$ cells were increased at 6 and 9 months and maintained until the end of the cycle. The frequency of CD $19^{+}$PD-L1 ${ }^{\text {int }}$ cells was significantly decreased at 6, 9, and 12 months following alemtuzumab. The absolute number of $\mathrm{CD} 19^{+} \mathrm{PD}-\mathrm{L} 1^{\text {int }}$ cells showed no significant difference. The frequency and absolute number of CD $19^{+}$PD-L1 ${ }^{\text {low }}$ cells showed no significant difference (Fig. 5a-c). 

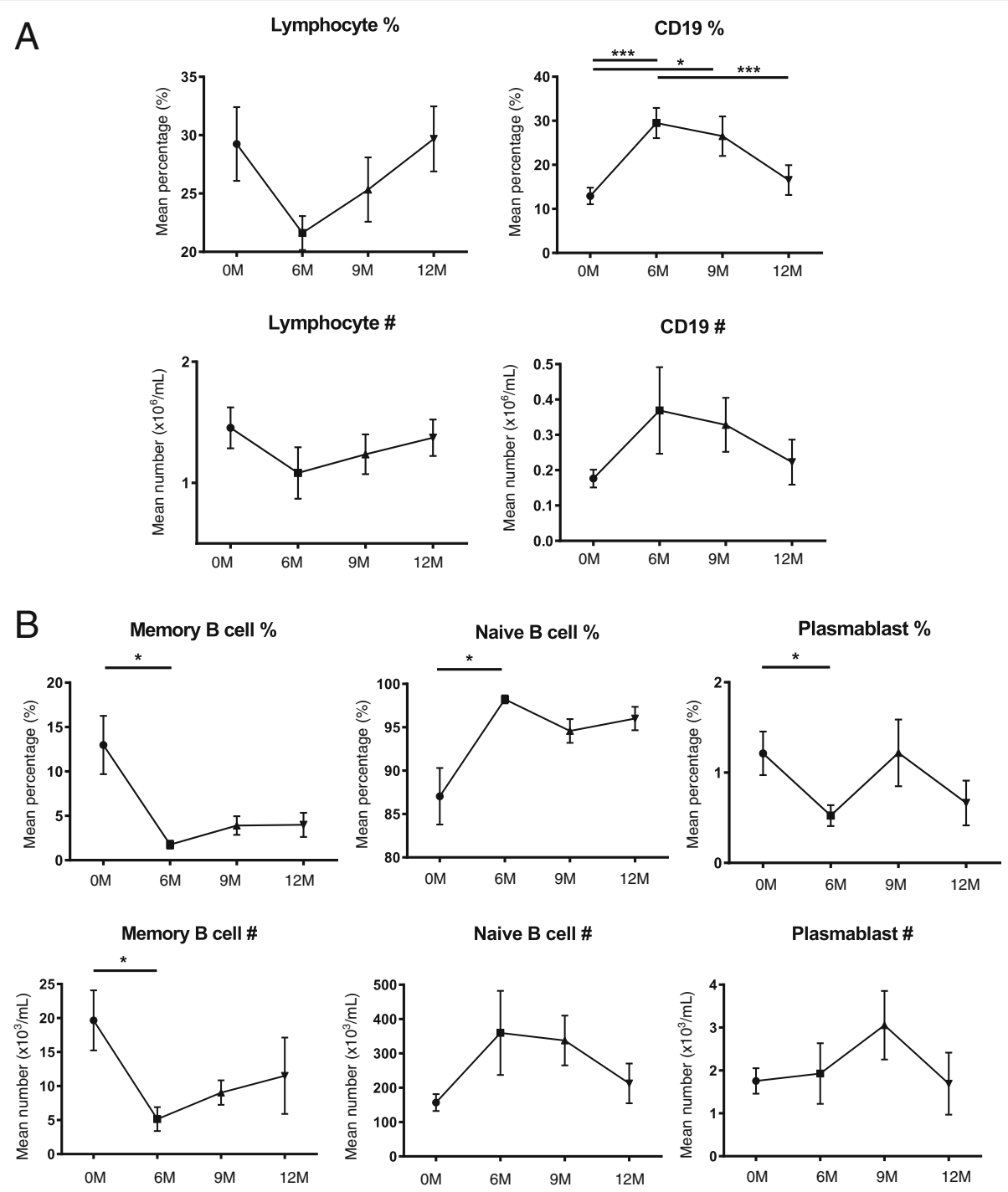

Fig. 3 Naive B cells predominate repopulated CD19+ cells following alemtuzumab treatment. In order to evaluate the B cell subset distribution post-alemtuzuamb, thawed PBMCs of alemtuzumab-treated patients $(n=11)$ were evaluated up to 12 months after induction. a Cumulative data for the frequency and the absolute number of total lymphocytes and CD19+ B cells. Successful depletion and reconstitution of lymphocytes and $\mathrm{CD} 19^{+} \mathrm{B}$ cells was confirmed. $\mathbf{b}$ Cumulative data for the frequency and the absolute number of $\mathrm{CD} 19^{+} \mathrm{CD} 27^{+}$memory B cells, $\mathrm{CD} 19^{+} \mathrm{CD} 27^{-}$naïve $\mathrm{B}$ cells, and $\mathrm{CD} 19^{+} \mathrm{CD} 27^{+} \mathrm{CD} 38^{\text {hi }}$ plasmablasts. Following alemtuzumab, significant reduction in the frequency of memory $\mathrm{B}$ cells $(6 \mathrm{M}$ vs $0 \mathrm{M}: p=$ 0.0278 ) and plasmablasts ( $6 \mathrm{M}$ vs $0 \mathrm{M}: p=0.0448$ ) was observed and dominance of naïve B cells was observed ( $6 \mathrm{M}$ vs $0 \mathrm{M}: p=0.0269)$. The absolute number of memory B cells was significantly decreased compared to $0 \mathrm{M}$ (6 M vs $0 \mathrm{M}: p=0.0112)$. All values show mean \pm SEM. Data were analyzed by repeated measures ANOVA with Tukey's multiple comparison post hoc analysis

\section{Clinical implications}

Among 11 patients treated with alemtuzumab, one patient experienced two severe relapses within 2 cycles of alemtuzumab infusion (Fig. 6a, b). During his first attack, overshoot of total B cells was observed while the frequency of $\mathrm{CD} 19^{+} \mathrm{CD} 24^{\text {hi }} \mathrm{CD} 38^{\text {hi }}$ cells was remarkably decreased to $0.45 \%$ compared to previous follow-up (6 M: 11.1\%). 4 months later, the frequency of $\mathrm{CD} 19^{+} \mathrm{CD} 24^{\mathrm{hi}} \mathrm{CD} 38^{\mathrm{hi}}$ cells increased to $6.5 \%$. 3 months post second alemtuzumab infusion, the frequency of $\mathrm{CD} 19^{+} \mathrm{CD} 24^{\text {hi }} \mathrm{CD} 38^{\text {hi }}$ cells was $10.5 \%$. However, at his second attack, $10 \mathrm{M}$ after second cycle infusion, the frequency of $\mathrm{CD}^{+} 9^{+} \mathrm{C}$ D24 ${ }^{\text {hi }} \mathrm{CD} 38^{\text {hi }}$ cells was again markedly decreased to $1.93 \%$ accompanied by overshooting $\mathrm{B}$ cell response. Interestingly, the reduction in the frequency of $\mathrm{CDa}$, b19 ${ }^{+} \mathrm{CD} 24^{\text {hi }}$ CD $38^{\text {hi }}$ cells (3.98\%) 20 days preceding second attack was observed, which is an immense reduction from previous follow-up (15 M: 10.5\%). In contrast to CD $19^{+}$CD24 ${ }^{\text {hi }}$ CD $38^{\text {hi }}$ cells, no change in the frequency of $\mathrm{CD} 19^{+} \mathrm{PD}-\mathrm{L} 1^{\text {hi }}$ cells was observed during both relapses. The absolute number of $\mathrm{CD} 19^{+} \mathrm{CD} 24^{\mathrm{hi}} \mathrm{CD} 38^{\text {hi }}$ cells was also reduced during relapses. 


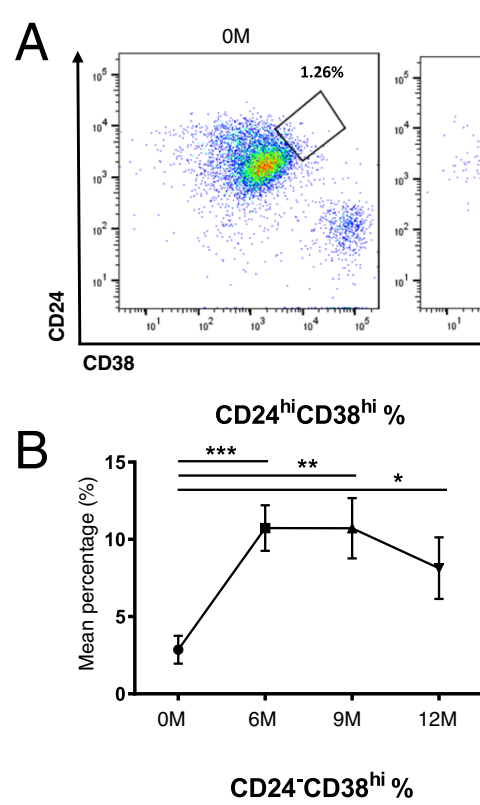

$6 \mathrm{M} \quad 12 \mathrm{M}$
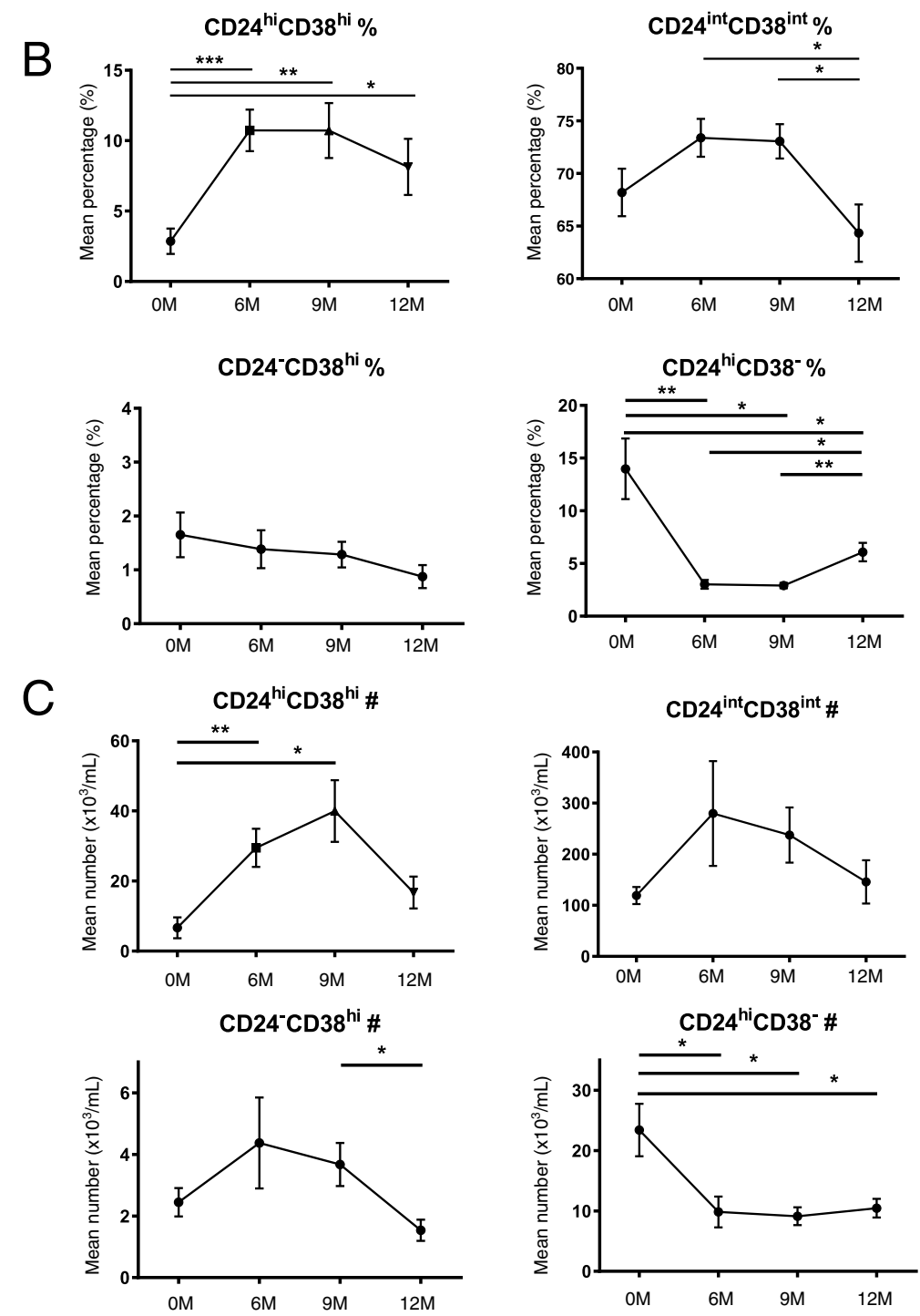

Fig. 4 Alemtuzumab treatment restores $C D 19^{+} C D 24^{\text {hi }} C D 38^{\text {hi }}$ cells. In order to evaluate the B cell subset distribution post-alemtuzuamb, thawed PBMCs of alemtuzumab-treated patients $(n=11)$ were evaluated up to 12 months after induction. a Representative flow-cytometry dot plot of CD24 and CD38 in total CD19 $B$ cells. $\mathbf{b}$. Cumulative data for the frequency of CD19+CD24 $4^{\text {hi }} C D 38^{\text {hi }} B$ cells. The frequency of CD19+CD24 ${ }^{\text {hi }} C D 38^{\text {hi }}$ cells were significantly increased at $6 \mathrm{M}$ and $9 \mathrm{M}$ compared to pre-treatment level ( $6 \mathrm{M}$ vs $0 \mathrm{M}: p=0.0004,9 \mathrm{M}$ vs $0 \mathrm{M}: p=0.0079)$. At $9 \mathrm{M}$, the frequency of $\mathrm{CD} 19^{+} \mathrm{CD} 24^{\mathrm{hi}} \mathrm{CD} 38^{\text {hi }}$ cells started to decrease and by $12 \mathrm{M}$, the frequency was reduced compared to $6 \mathrm{M}$, although it was significantly increased than baseline level (12 M vs $0 \mathrm{M}: p=0.0257)$. $\mathbf{c}$ The absolute number was significantly increased at $6 \mathrm{M}$ and $9 \mathrm{M}$ post-alemtuzumab (6 M vs $0 \mathrm{M}: p=0.0063,9 \mathrm{M}$ vs $0 \mathrm{M}: p=0.02$ ). All values show mean \pm SEM. Data were analyzed by repeated measures ANOVA with Tukey's multiple comparison post-hoc analysis. ${ }^{*} p<0.05 ;{ }^{* *} p<0.01 ;{ }^{* * *} p<0.001$ 


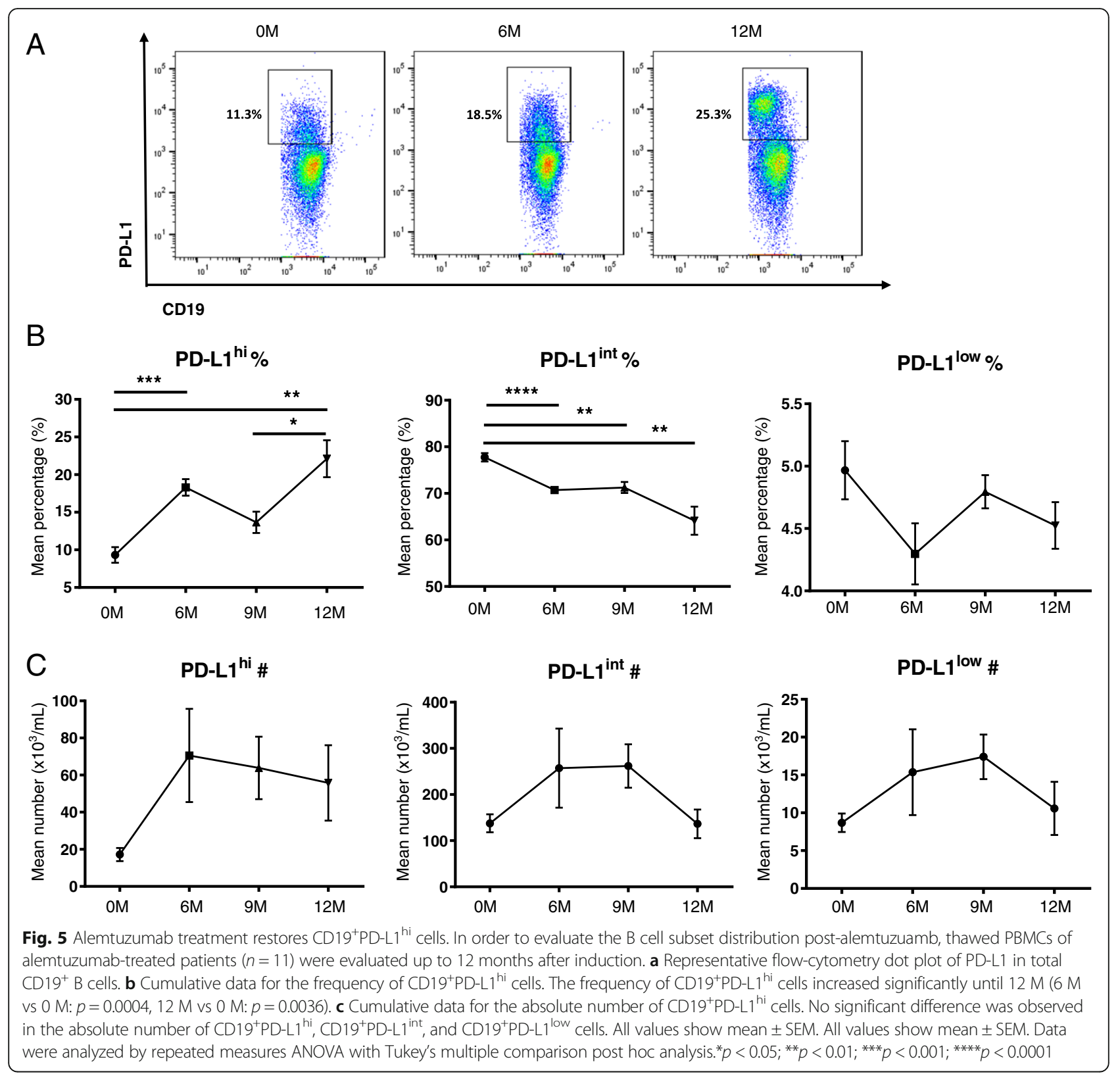

\section{Discussion}

Little is known about the repopulating B cell pool following alemtuzumab. Cases of severely exacerbated central nervous system inflammation in alemtuzumab-treated MS patients have reported B-cell driven pathology, further emphasizing the importance of B cell study in alemtuzumab-treated patients [13-15]. We show that deficiency of $\mathrm{CD} 19^{+} \mathrm{CD} 24^{\mathrm{hi}} \mathrm{CD} 38^{\text {hi }}$ cells and $\mathrm{CD} 19^{+} \mathrm{PD}-\mathrm{L} 1^{\text {hi }}$ cells in the peripheral blood of relapsing MS patients are restored following alemtuzumab and that B cell distribution shifts towards naïve phenotype. In fact, the frequency of Bregs with disparate regulatory mechanisms exceeded baseline level, which may underlie the long-lasting suppression of disease activity.
Interestingly, both frequency and absolute number of $\mathrm{CD} 19^{+} \mathrm{CD} 24^{\mathrm{hi}} \mathrm{CD} 38^{\mathrm{hi}}$ cells are reduced during and prior to relapse in an alemtuzumab-treated patient. CD1 $9^{+} \mathrm{CD} 24^{\text {hi }} \mathrm{CD} 38^{\text {hi }}$ cells are known to maintain Tregs and limit the differentiation of $\mathrm{T}$ helper 1 (Th1) and T helper 17 (Th17) cells [16]. The deficiency of $\mathrm{CD} 19^{+} \mathrm{C}$ D2 $4{ }^{\text {hi }} \mathrm{CD} 38^{\text {hi }}$ cells could have a significant impact on the regulation of pathology. Indeed, recent studies have found that transitional B cells are impaired in various immune-related disorders [7, 16-18], although conflicting results were observed in MS. [19, 20] In the early phase of alemtuzumab therapy, $\mathrm{CD} 19^{+} \mathrm{B}$ cells repopulate earlier than $\mathrm{CD} 4+\mathrm{T}$ cells and immature $\mathrm{B}$ cells dominate the repopulated CD19+ B cells [21]; the 


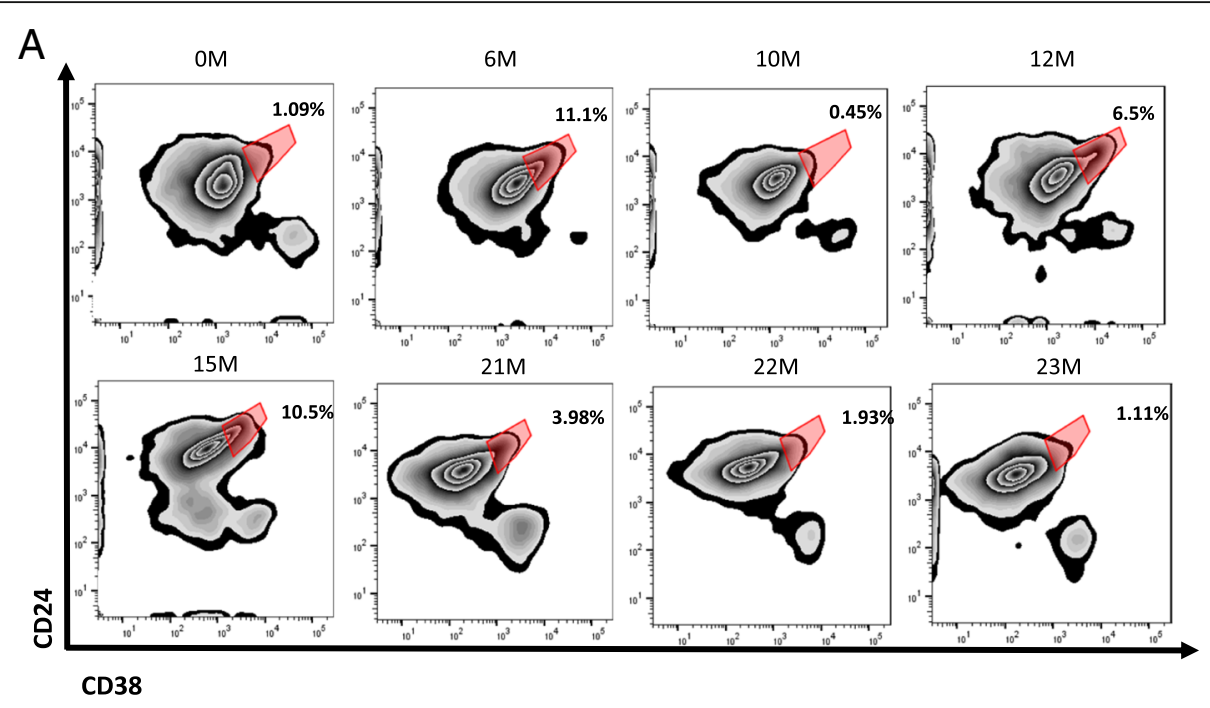

B

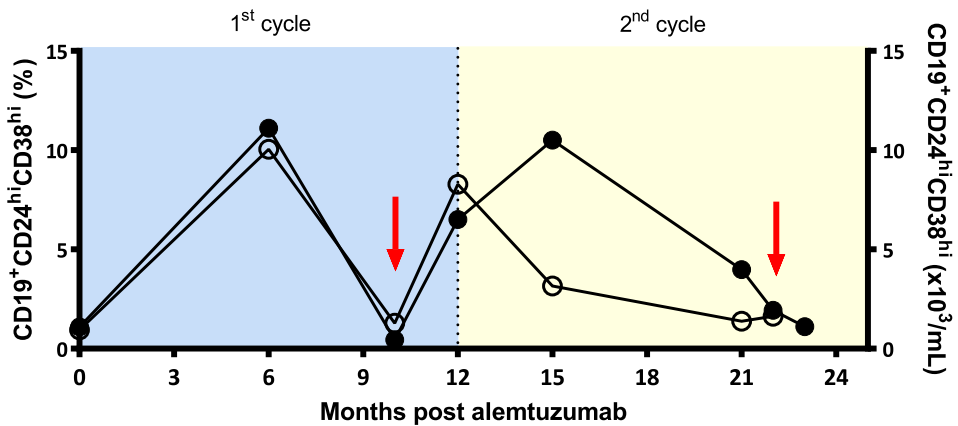

Fig. 6 The frequency of $\mathrm{CD} 19^{+} \mathrm{CD} 24^{\text {hi }} \mathrm{CD} 38^{\text {hi }}$ cells is decreased during relapse post alemtuzumab treatment. a Flow-cytometry plot of expression of CD24 and CD38 in total CD19+ B cells. $\mathbf{b}$ Graph showing the clinical course. The frequency and the absolute number of CD19 $C D 24^{\text {hi }} C D 38^{\text {hi }} B$ cells and infusion of 2 cycles of alemtuzumab are shown. Filled circles indicate the frequency of $C D 19^{+} C D 24^{\text {hi }} C D 38^{\text {hi }} B$ cells, and hollow circles indicate the absolute number of $\mathrm{CD} 19^{+} \mathrm{CD} 24^{\mathrm{hi}} \mathrm{CD} 38^{\mathrm{hi}} \mathrm{B}$ cells. Red arrow indicates relapse

extensive repopulation of $\mathrm{CD} 19^{+} \mathrm{CD} 24^{\text {hi }} \mathrm{CD} 38^{\text {hi }}$ cells following alemtuzumab may contribute to the expansion of Tregs while suppressing differentiation of naïve $\mathrm{CD} 4^{+}$ $\mathrm{T}$ cells into Th1 and Th17 cells and hence, contributing to the efficacy of alemtuzumab.

A recent study described that $\mathrm{CD} 19^{+} \mathrm{PD}-\mathrm{L} 1^{\text {hi }}$ cells are capable of suppressing Tfh cell differentiation and expansion through interaction with PD-1 on activated $\mathrm{T}$ cells [8]. Interaction causes an increase in signal transducer and activator of transcription 5 expression, a known suppressor of Tfh-cell development and expansion. Since Tfh cells aid germinal center formation and hence, involved in the formation of memory B cells and plasma cells, Tfh cells were thought to have pathogenic role in the B-cell-mediated autoimmune diseases. There has been several reports on Tfh cell involvement in MS. [22-25] Most of all, there has been report that CCR7 ${ }^{+}$ $\mathrm{ICOS}^{+}$circulating memory Tfh cells are increased in MS patients during relapse, but decreased in patients during remission [9]. This finding is in line with our results, where $\mathrm{CD} 19^{+} \mathrm{PD}-\mathrm{L} 1^{\text {hi }}$ cells are decreased in MS patients during relapse, but restored during remission. Hence, suppression of Tfh cell differentiation and proliferation by $\mathrm{CD} 19^{+} \mathrm{PD}-\mathrm{L} 1^{\text {hi }}$ cells may be impaired due to $\mathrm{CD} 19+$ PD-L1hi cell deficiency, contributing to enhancement of disease activity.

This study is limited by its small sample size. In addition, we report that the marked reduction of $\mathrm{CD} 19^{+} \mathrm{CD} 24^{\mathrm{hi}} \mathrm{CD} 38^{\mathrm{hi}}$ cells during relapse in an alemtuzumab-treated patient was observed in only 2 relapses of a single case. Therefore, in order to decipher the critical role of $\mathrm{CD} 19^{+} \mathrm{CD} 24^{\mathrm{hi}} \mathrm{CD} 38^{\mathrm{hi}}$ cells in the long-term disease suppression of MS and in the mechanism of action of alemtuzumab, further longitudinal study with larger number of patients on how $\mathrm{CD} 19^{+} \mathrm{CD} 24^{\mathrm{hi}} \mathrm{CD} 38^{\text {hi }}$ cells and other lymphocytes (including Tregs) change during relapse, is required. The extensive expansion of $\mathrm{CD} 19^{+} \mathrm{CD} 24^{\mathrm{hi}} \mathrm{CD} 38^{\mathrm{hi}}$ cells was maintained until 9 months post-alemtuzumab, whereas $\mathrm{CD} 19^{+} \mathrm{PD}-\mathrm{L} 1^{\text {hi }}$ cells were maintained until the end of the cycle. Further work needs to be established to explain the difference in the results. In addition, a recent 
study has reported that hyperrepopulation of immature $B$ cells post-alemtuzumab in the absence of adequate regulation by $\mathrm{T}$ cells increases the risk of secondary autoimmunity [21]. Due to vast composition of immature B cells and lack of understanding of their function, it remains to be further elucidated which specific immature B cell subset would be responsible for the secondary autoimmunity. Lastly, further functional study on the $\mathrm{CD} 19^{+} \mathrm{CD} 24^{\mathrm{hi}} \mathrm{CD} 38^{\mathrm{hi}}$ cells would clarify the mechanism of action of alemtuzumab.

\section{Conclusion}

Our results highlight the preferential reconstitution of Bregs as a possible mechanism of action of alemtuzumab and $\mathrm{CD} 19^{+} \mathrm{CD} 24^{\mathrm{hi}} \mathrm{CD} 38^{\text {hi }}$ cells as a potential biomarker for disease activity.

\section{Abbreviations}

Bregs: Regulatory B cells; $\mathrm{CD} 19^{+} \mathrm{CD} 24^{\text {hi }} \mathrm{CD} 38^{\text {hi }}$ : Transitional B cells; HC: Healthy controls; MS: Multiple sclerosis; MS-relapse: MS patients during relapse; MS-remission: MS patients in remission; PBMC: Peripheral blood mononuclear cells; PD-L1: Programmed death-ligand 1; Tfh: T follicular helper cells; Th1: T helper 1; Th17: T helper 17; Tregs: Regulatory T cells

\section{Acknowledgements}

Not applicable.

\section{Funding}

This study was supported by the Bio \& Medical Technology Development Program (NRF-M3A9B6069339) and the Advanced Research Center Program (NRF-2018R1A5A2023127) of the National Research Foundation funded by the Ministry of Science \& ICT.

\section{Availability of data and materials}

All data generated or analyzed during this study are included in this published article.

\section{Authors' contributions}

KYS had full access to all of the data in the study and take responsibility for the integrity of the data and the accuracy of the data analysis. KYS and KHJ contributed to the study concept and design, and drafting of the manuscript. KYS and SHJ helped in the acquisition of data. All authors helped in the analysis and interpretation of data, and critical revision of the manuscript for intellectual content. KYS carried out the statistical analysis. KHJ supervised the study. All authors read and approved the final manuscript.

\section{Ethics approval and consent to participate}

The Institutional Review Board of NCC approved the present study, and written informed consent was obtained from all participants.

\section{Consent for publication}

Not applicable.

\section{Competing interests}

Kim YS, Kim GY, Hyun JW, Kim SH, and Shin HJ report no conflicts of interest. Kim HJ has lectured, consulted, and received honoraria from Bayer Schering Pharma, Biogen, Celltrion, Eisai, Genzyme, HanAll BioPharma, Medlmmune, Merck Serono, Novartis, Teva-Handok, and UCB; received a grant from National Research Foundation of the Ministry of Science and ICT; and accepted research funding from Genzyme, Merck Serono, Teva-Handok, and UCB; serves on a steering committee for Medlmmune; is a co-editor for the Multiple Sclerosis Journal-Experimental, Translational, and Clinical, and an associated editor for the Journal of Clinical Neurology.

\section{Publisher's Note}

Springer Nature remains neutral with regard to jurisdictional claims in published maps and institutional affiliations.

\section{Author details}

${ }^{1}$ Division of Clinical Research, Research institute, National Cancer Center, Goyang, Korea. ${ }^{2}$ Department of Neurology, Research Institute and Hospital of National Cancer Center, Goyang, Korea. ${ }^{3}$ Yonsei University College of Medicine, Seoul, Korea.

Received: 29 April 2018 Accepted: 15 October 2018

Published online: 30 October 2018

References

1. Bar-Or A, Fawaz L, Fan B, Darlington PJ, Rieger A, Ghorayeb C, Calabresi PA, Waubant E, Hauser SL, Zhang J, Smith CH. Abnormal B-cell cytokine responses a trigger of T-cell-mediated disease in MS? Ann Neurol. 2010;67:452-61.

2. Owens GP, Bennett $J$, Gilden DH, Burgoon MP. The B cell response in multiple sclerosis. Neurol Res. 2006;28:236-44.

3. Hauser SL, Waubant E, Arnold DL, Vollmer T, Antel J, Fox RJ, Bar-Or A, Panzara M, Sarkar N, Agarwal S, et al. B-cell depletion with rituximab in relapsing-remitting multiple sclerosis. N Engl J Med. 2008;358:676-88.

4. Weber MS, Hemmer B, Cepok S. The role of antibodies in multiple sclerosis. Biochim Biophys Acta. 1812;2011:239-45.

5. Duddy M, Niino M, Adatia F, Hebert S, Freedman M, Atkins H, Kim HJ, Bar-Or A. Distinct effector cytokine profiles of memory and naive human B cell subsets and implication in multiple sclerosis. J Immunol. 2007;178:6092-9.

6. Knippenberg S, Peelen E, Smolders J, Thewissen M, Menheere P, Cohen Tervaert JW, Hupperts R, Damoiseaux J. Reduction in IL-10 producing B cells (Breg) in multiple sclerosis is accompanied by a reduced naive/memory Breg ratio during a relapse but not in remission. J Neuroimmunol. 2011;239:80-6.

7. Blair PA, Norena LY, Flores-Borja F, Rawlings DJ, Isenberg DA, Ehrenstein MR, Mauri C. CD19(+)CD24(hi)CD38(hi) B cells exhibit regulatory capacity in healthy individuals but are functionally impaired in systemic lupus erythematosus patients. Immunity. 2010;32:129-40.

8. Khan AR, Hams E, Floudas A, Sparwasser T, Weaver CT, Fallon PG. PD-L1hi B cells are critical regulators of humoral immunity. Nat Commun. 2015;6:5997.

9. Fan $X$, Jin T, Zhao S, et al. Circulating CCR7+ICOS+ Memory T Follicular Helper Cells in Patients with Multiple Sclerosis. PLoS One. 2015;10(7):e0134523.

10. Zhang X, Tao Y, Chopra M, Ahn M, Marcus KL, Choudhary N, Zhu H, MarkovicPlese S. Differential reconstitution of T cell subsets following immunodepleting treatment with alemtuzumab (anti-CD52 monoclonal antibody) in patients with relapsing-remitting multiple sclerosis. J Immunol. 2013;191:5867-74.

11. Havari E, Turner MJ, Campos-Rivera J, Shankara S, Nguyen TH, Roberts B, Siders W, Kaplan JM. Impact of alemtuzumab treatment on the survival and function of human regulatory T cells in vitro. Immunology. 2014;141:123-31.

12. Polman CH, Reingold SC, Banwell B, Clanet M, Cohen JA, Filippi M, Fujihara K, Havrdova E, Hutchinson M, Kappos L, et al. Diagnostic criteria for multiple sclerosis: 2010 revisions to the McDonald criteria. Ann Neurol. 2011;69:292-302.

13. Haghikia A, Dendrou CA, Schneider R, Gruter T, Postert T, Matzke M, Stephanik H, Fugger L, Gold R. Severe B-cell-mediated CNS disease secondary to alemtuzumab therapy. Lancet Neurol. 2017;16:104-6.

14. Wehrum T, Beume LA, Stich O, Mader I, Maurer M, Czaplinski A, Weiller C, Rauer S. Activation of disease during therapy with alemtuzumab in 3 patients with multiple sclerosis. Neurology. 2018;90:e601-5.

15. Rinaldi F, Federle L, Puthenparampil M, Perini P, Grassivaro F, Gallo P. Evidence of B-cell dysregulation in severe CNS inflammation after alemtuzumab therapy. Neurol Neuroimmunol Neuroinflamm. 2018;5:e420.

16. Flores-Borja F, Bosma A, Ng D, Reddy V, Ehrenstein MR, Isenberg DA, Mauri C. CD19+CD24hiCD38hi B cells maintain regulatory T cells while limiting TH1 and TH17 differentiation. Sci Transl Med. 2013;5:173ra123.

17. Newell KA, Asare A, Kirk AD, Gisler TD, Bourcier K, Suthanthiran M, Burlingham WJ, Marks WH, Sanz I, Lechler Rl, et al. Identification of a B cell signature associated with renal transplant tolerance in humans. J Clin Invest. 2010;120:1836-47.

18. Lee-Chang C, Top I, Zephir H, Dubucquoi S, Trauet J, Dussart P, Prin L, Vermersch P. Primed status of transitional B cells associated with their presence in the cerebrospinal fluid in early phases of multiple sclerosis. Clin Immunol. 2011;139:12-20. 
19. Haas J, Bekeredjian-Ding I, Milkova M, Balint B, Schwarz A, Korporal M, Jarius S, Fritz B, Lorenz HM, Wildemann B. B cells undergo unique compartmentalized redistribution in multiple sclerosis. J Autoimmun. 2011;37:289-99.

20. Guerrier T, Labalette M, Launay D, Lee-Chang C, Outteryck O, Lefevre G, Vermersch P, Dubucquoi S, Zephir H. Proinflammatory B-cell profile in the early phases of MS predicts an active disease. Neurol Neuroimmunol Neuroinflamm. 2018:5:e431.

21. Baker D, Herrod SS, Alvarez-Gonzalez C, Giovannoni G, Schmierer K. Interpreting lymphocyte reconstitution data from the pivotal phase 3 trials of Alemtuzumab. JAMA Neurol. 2017;74:961-9.

22. Piccio L, Naismith RT, Trinkaus K, Klein RS, Parks BJ, Lyons JA, Cross AH. Changes in B- and T-lymphocyte and chemokine levels with rituximab treatment in multiple sclerosis. Arch Neurol. 2010;67:707-14.

23. Krumbholz M, Theil D, Cepok S, Hemmer B, Kivisakk P, Ransohoff RM, Hofbauer M, Farina C, Derfuss T, Hartle C, et al. Chemokines in multiple sclerosis: CXCL12 and CXCL13 up-regulation is differentially linked to CNS immune cell recruitment. Brain. 2006:129:200-11.

24. Magliozzi R, Howell O, Vora A, Serafini B, Nicholas R, Puopolo M, Reynolds R, Aloisi F. Meningeal B-cell follicles in secondary progressive multiple sclerosis associate with early onset of disease and severe cortical pathology. Brain. 2007;130:1089-104.

25. Serafini B, Rosicarelli B, Magliozzi R, Stigliano E, Aloisi F. Detection of ectopic B-cell follicles with germinal centers in the meninges of patients with secondary progressive multiple sclerosis. Brain Pathol. 2004;14:164-74.

Ready to submit your research? Choose BMC and benefit from:

- fast, convenient online submission

- thorough peer review by experienced researchers in your field

- rapid publication on acceptance

- support for research data, including large and complex data types

- gold Open Access which fosters wider collaboration and increased citations

- maximum visibility for your research: over $100 \mathrm{M}$ website views per year

At $\mathrm{BMC}$, research is always in progress.

Learn more biomedcentral.com/submissions 